\title{
Temporal Variation in Composition and Abundance of Phytoplankton Species during 2011 and 2012 in Acapulco Bay, Mexico
}

\author{
Giovanni Moreno-Díaz', Agustín A. Rojas-Herrera², Juan Violante-González², \\ Justiniano González-González ${ }^{1}$, José Luis Rosas Acevedoํㅜ, Sergio García Ibáñez ${ }^{2}$ \\ ${ }^{1}$ Unidad de Ciencias de Desarrollo Regional, Universidad Autónoma de Guerrero, Acapulco, México \\ ${ }^{2}$ Unidad Académica de Ecología Marina, Universidad Autónoma de Guerrero, Acapulco, México \\ Email: acu.amar@hotmail.com
}

Received 13 June 2015; accepted 26 July 2015; published 30 July 2015

Copyright (C) 2015 by authors and Scientific Research Publishing Inc.

This work is licensed under the Creative Commons Attribution International License (CC BY).

http://creativecommons.org/licenses/by/4.0/

c) (i) Open Access

\begin{abstract}
Phytoplankton samples were collected in Acapulco Bay during 2011 (January-April and September) and 2012 (April-July, October, and November) with the objective of determining the abundance and species composition. Samples were collected in two stations located in the bay. A total of 82 species were identified: 42 dinoflagellates, 35 diatoms, three cyanobacteria, and two silicoflagellates. Dinoflagellates were more abundant in the dry season, while diatoms dominated during rainy season. At least seven dinoflagellate species were recorded as potentially toxic, which may increase their populations and turn into harmful algal blooms (HABs) if environmental conditions within the bay are modified. In April 2012 a HAB of the non-toxic species Neoceratium balechii was documented.
\end{abstract}

\section{Keywords}

Marine Phytoplankton, Species Composition, Acapulco Bay, Mexico

\section{Introduction}

Phytoplankton is one of the most complex communities in marine coastal environments. This community's structure is dictated by two important groups of organisms: i) non-motile, fast-growing diatoms; and ii) motile flagellates and dinoflagellates which can migrate vertically in the water column in response to light. All phytoplankton species are subject to water currents and have developed strategies for rapid nutrient absorption and fast reactions to fluctuations in hydrographic conditions [1]. Thus, phytoplankton distribution and species composi-

How to cite this paper: Moreno-Díaz, G., Rojas-Herrera, A.A., Violante-González, J., González-González, J., Acevedo, J.L.R. and Ibáñez, S.G. (2015) Temporal Variation in Composition and Abundance of Phytoplankton Species during 2011 and 2012 in Acapulco Bay, Mexico. Open Journal of Marine Science, 5, 358-367. http://dx.doi.org/10.4236/ojms.2015.53029 
tion are affected by several processes, including high water temperature, and variations in thermal stability and nutrient circulation. Changes can occur in the taxonomic composition of phytoplankton communities, the total cell abundance and species richness during annual seasonal cycles. These changes reflect the capacity of communities to respond to seasonal variations in light, nutrient and circulation patterns [2].

Santa Lucia Bay, also known as Acapulco Bay, is located on the tropical Pacific coast of southern Mexico, in Guerrero State. The bay has a semi-circular (6.3 km diameter), amphitheater-like shape created by low hills $(<500 \mathrm{~m})$ surrounding the south-facing bay. It is considered to be very climatologically protected [3]. Nevertheless the ecological importance of the bay, because it operates as nursery for many fish species, which feed inside the same, very few studies have been carried out on the phytoplankton communities and in particular on the variation in the species composition through time [3] [4]. The aim of the present study was to examine the temporal variation, in the species composition and abundance in the phytoplankton community of Acapulco Bay, during two years.

\section{Materials and Methods}

Phytoplankton samples were collected in Acapulco Bay between January-April and September 2011, and April-July, October, and November 2012. Two sampling stations were established within the study area: 1Morro San Lorenzo $\left(16^{\circ} 51^{\prime} \mathrm{N}, 99^{\circ} 53^{\prime} \mathrm{W}\right)$ and 2-Casa de Díaz Ordaz $\left(16^{\circ} 50^{\prime} \mathrm{N}, 99^{\circ} 51^{\prime} \mathrm{W}\right)$. Water temperature $\left({ }^{\circ} \mathrm{C}\right)$, salinity (psu), dissolved oxygen $(\mathrm{mg} / \mathrm{L})$, and chlorophyll $(\mu \mathrm{g} / \mathrm{L})$ were measured in situ with an YSI probe. Nutrient (nitrates, ammonium and phosphates) concentrations were determined in each sampling following a standard colorimetric method (Hanna equip). Samples were taken using a plankton net of $31 \mathrm{~cm}$ diameter, $1.28 \mathrm{~m}$ length, and $150 \mu \mathrm{m}$ mesh size. Phytoplankton samples were fixed in concentrated Lugol's solution and cell quantification was made using the Utermöhl chamber sedimentation concentration method. Phytoplankton species distribution was established based on a review of published records for Mexico and other countries, and each species was classified as: 1) estuarine; 2) neritic; 3) adiaphoric or 4) oceanic. The Olmstead-Tukey association test [5] was applied to classify the phytoplankton species based on parameters of occurrence frequency and mean abundance: (D) dominant (abundant and frequent); (C) common (low abundance but frequent); (O) occasional (abundant but low frequency); and (R) rare (low abundance and low frequency). Community parameters included total number of species, total number of cells, the Shannon-Wiener $(\mathrm{H})$ diversity index, species evenness (J) and theBerger-Parker Index (BPI) as a measure of numerical dominance [6] [7]. Similarity in the species composition throughout the sampling period was established with a classification analysis considering abundance (number of cells), using the Bray-Curtis index and simple average-group method [8]. A principal component analysis (PCA) was made using monthly data that included: temperature, salinity, precipitation, phosphates, chlorophyll, oxygen, nitrates, nitrites, and abundance of dinoflagellates and diatoms.

\section{Results}

Mean temperature recorded at the sampled stations varied between $24.55^{\circ} \mathrm{C}$ and $30.55^{\circ} \mathrm{C}$, during the period of January 2011 to November 2012 (Table 1). Salinity varied from 31.4 to 33.7 psu. Dissolved oxygen presented the lowest mean value in April 2012 (2 mg/L) and the highest in March and September 2012 (10 mg/L) (Table 1).

In regards of nutrients, the lowest average values for nitrites occurred in June $2011(0.0)$ and the higher in March and September 2011 (0.03). Nitrates ranged from 0.0 to $0.6 \mathrm{mg} / \mathrm{l}$, where the lowest average value was found in May 2012 (0.0) and the highest in March 2011 (0.45). Phosphates ranged from 0.0 to $2.75 \mathrm{mg} / \mathrm{L}$, the lowest average value occurred in January 2011 (0.11) and the highest in September 2011 (1.43) (Table 1).

The lowest average value recorded for chlorophyll was found in November 2012 (1.2) and the highest in July 2011 (1.95). The highest values were recorded from November to December (Table 1).

Regarding the community analysis based on eigenvalues and saturation of variables, three components were extracted with $75 \%$ of the total explained variance (Table 2(a)). The first component was catalogued as "Chlorophyll pattern", where an increase in phosphates and a decrease in chlorophyll and salinity is recorded as temperature increases; thus a great quantity of phosphates and nitrates were firstly observed and then an increase in chlorophyll, which coincides with a similar behavior of salinity.

The second component was catalogued as "diversity performance", where an increase in the phytoplanktonic 
Table 1. Physical-chemical parameters of seawater from Acapulco Bay, Guerrero, Mexico. Precipitation (mm), Temperature $\left({ }^{\circ} \mathrm{C}\right)$, Salinity (\%o), Dissolved oxygen (mg/l), Chlorophyll ( $\left.\mu \mathrm{g} / \mathrm{l}\right)$, Phosphates, nitrites, and nitrates (mg/l).

\begin{tabular}{lcccccccc}
\hline & Precipitation & Temperature & Salinity & Chlorophyll & Nitrites & Nitrates & Phosphates & Oxygen \\
\hline JAN_11 & 0 & 26.07 & 33.36 & 1.65 & & 0.3 & 0.11 & 5.8 \\
FEB_11 & 0 & 27.67 & 33.38 & 1.55 & 0.01 & 0.35 & 0.22 & 5 \\
MAR_11 & 0.7 & 26.17 & 33.58 & 1.8 & 0.03 & 0.45 & 0.29 & 10 \\
APR_11 & 9.6 & 26.17 & 33.58 & 1.8 & 0.03 & 0.45 & 0.29 & 10 \\
SEP_11 & 158 & 30 & 31.41 & 1.4 & 0.03 & 1.4 & 1.44 & 10 \\
APR_12 & 4.9 & 28.01 & 33.7 & 1.55 & 0.03 & 0.3 & 0.33 & 2 \\
MAY_12 & 38.4 & 30.55 & 33.24 & 1.35 & 0.01 & 0.1 & 1.38 & 9.05 \\
JUN_12 & 217.1 & 27.66 & 33.24 & 1.45 & 0.06 & 0 & 0.2 & 8.5 \\
JUL_12 & 150.9 & 29.39 & 32.86 & 1.95 & 0.03 & 0.3 & 0.13 & 6.81 \\
OCT_12 & 98.8 & 29.79 & 33.09 & 1.5 & & & & 7.47 \\
NOV_12 & 10.7 & 29.5 & 32.9 & 1.2 & 0.03 & 0.17 & 0.98 & 6.54 \\
\hline
\end{tabular}

Table 2. Method of extraction of the PCA variables recorded in Acapulco Bay, Guerrero, Mexico.

(a)

\begin{tabular}{cccc}
\hline Variables & I & II & III \\
\hline Phosphates & 0.870 & 0.271 & -0.077 \\
Temperature & 0.867 & 0.008 & 0.081 \\
Chlorophyll & -0.776 & 0.210 & 0.081 \\
Salinity & -0.710 & -0.443 & -0.373 \\
Oxygen & 0.019 & 0.879 & 0.230 \\
H & -0.061 & 0.843 & -0.244 \\
Nitrates & 0.419 & 0.523 & 0.101 \\
Precipitation & 0.248 & 0.173 & 0.868 \\
Nitrites & -0.193 & -0.111 & 0.867 \\
\hline
\end{tabular}

(b)

\begin{tabular}{ccc}
\hline Variables & I & II \\
\hline Temperature & 0.902 & -0.008 \\
Phosphates & 0.897 & 0.161 \\
Chlorophyll & -0.731 & 0.092 \\
Oxygen & 0.068 & 0.702 \\
Precipitation & 0.176 & 0.678 \\
Salinity & -0.658 & -0.662 \\
Dinoflagellates & 0.191 & -0.651 \\
Nitrates & 0.370 & 0.608 \\
Nitrites & -0.273 & 0.449 \\
\hline
\end{tabular}


(c)

\begin{tabular}{ccc}
\hline Variables & I & II \\
\hline Temperature & 0.903 & -0.010 \\
Phosphates & 0.898 & 0.159 \\
Chlorophyll & -0.729 & 0.092 \\
Oxygen & 0.071 & 0.700 \\
Precipitation & 0.179 & 0.678 \\
Salinity & -0.659 & -0.662 \\
Diatoms & -0.203 & 0.650 \\
Nitrates & 0.371 & 0.606 \\
Nitrites & -0.271 & 0.452 \\
\hline
\end{tabular}

diversity and nitrates occurs as high oxygen levels are found. The third component was catalogued as "rain effect”, where an increase of precipitations was related to an increase in nitrites.

According to the dinoflagellate population analysis, considering eigenvalues and saturation of variables, two components were extracted with a total explained variance of 58\% (Table 2(b)). The first component was catalogued as "temperature effect", where an increase of phosphates and a decrease in the quantity of chlorophyll occur as temperature increases. The second component was catalogued as "oxygen effect” where an increase in such factor was related to an increase in precipitation, nitrates, and nitrites, and also to a decrease in both salinity and dinoflagellate population.

Concerning the population analysis for the diatom group, two components with a total explained variance of $58 \%$ (Table 2(c)) were extracted. The first component presented the same behavior as the aforementioned case. Both components presented a similar performance to the found in the dinoflagellate analysis, the only difference is that when oxygen and precipitation increase, the diatom population also increase.

The taxonomic composition analysis of the phytoplankton community indicated that a total of 82 species comprised the community within the bay: 42 dinoflagellates (Dinophyta), 32 diatoms (Bacillariophyta), three blue-green algae (Cyanobacteria), and two silicoflagellates (Heterokontophyta) (Table 3). Although the number of diatom species was relatively low, this group's total cell abundance represented the $51.7 \%$ of the total cells collected during the sampling period. The most important genus were Neoceratium (22 species), and Chaetoceros (8 species).

The discrimination of species groups indicated that dinoflagellates dominated numerically during March 2011 as well as in April, May, July, and November 2012; during April, the relative density of dinoflagellates was $100 \%$ given the occurrence of an algal bloom where the dominant species was Neoceratium balechii with $89.52 \%$ of relative abundance; while diatoms recorded an inversely proportional relationship to dinoflagellate abundance (Table 3). Nine species dominated the phytoplankton community numerically: five dinoflagellate species (Neoceratium balechii, $N$. tripos, $N$. deflexum, $N$. trichoceros, and $N$. furca) and four diatoms (Chaetoceros sp., Rhizosolenia hebetata, Chaetoceros affinis, and Ch. didymus) (Table 3 and Table 4). These nine species represented $65.5 \%$ of the total of cells estimated for all of the samplings. The dinoflagellate Neoceratium furca was collected at all sampling months, Neoceratium balechii was dominant in April 2012 when the massive bloom of this species occurred, and Neoceratium tripos was dominant in May and July 2012. The diatoms Chaetoceros sp. and Rhizosolenia hebetata were also present in all of the months excepting April 2012, where diatoms were absent.

According to the classification of species based on its origin, more than $70 \%$ of diatoms and dinoflagellates were classified as adiaphoric species (species that occur in both neritic and oceanic zones), where the percentage of neritic and oceanic species was 16.5 and 9.8\% for both groups respectively. The application of a graphic method of classification based on species frequency and abundance, indicated that $22.8 \%$ of the diatoms were classified as dominant (abundant and frequent), while 16.6\% of dinoflagellates presented the same classification.

Species richness ranged from seven (April 2012) to 38 species (April 2011). 
Table 3. Relative composition of abundance of the phytoplankton community in Acapulco Bay, Mexico. Distribution: $1=$ Estuarine, 2 = Neritic, 3 = Adiaphoric, 4 = Oceanic. Classification: $(D)$ Dominant, $($ F) Frequent, $(\mathrm{O})=$ Occasional, $(\mathrm{R})=$ Rare.

\begin{tabular}{|c|c|c|c|c|c|c|c|c|c|c|c|}
\hline Species & Jan. & Feb. & Mar. & Apr. & Sep. & Apr. & May. & Jun. & Jul. & Oct. & Nov. \\
\hline \multicolumn{12}{|l|}{ Dinophyta } \\
\hline $\begin{array}{l}\text { Amphisolenia bidentata } \\
\text { Schröder, } 1900^{3(\mathrm{R})}\end{array}$ & & 0.439 & & & & & & & & & \\
\hline $\begin{array}{l}\text { Amphisolenia lemmermannii } \\
\text { Kofoid, } 1907^{3(\mathrm{R})}\end{array}$ & & & & & & 0.551 & 0.462 & & & & \\
\hline Amphisolenia sp. ${ }^{(\mathrm{R})}$ & 0.259 & & & & & & & & 0.195 & & \\
\hline Ceratocorys horrida Stein, $1883^{3(\mathrm{R})}$ & & 0.146 & & 0.162 & & & & & & & \\
\hline $\begin{array}{l}\text { Dinophysis caudata } \\
\text { Saville-Kent, } 1881^{3(\mathrm{~F})}\end{array}$ & 0.129 & 3.665 & & & & & 2.777 & 1.417 & 1.367 & 1.086 & \\
\hline Gonyaulax sp. ${ }^{(\mathrm{F})}$ & & 0.146 & & & 0.992 & 2.757 & & & 0.585 & 2.795 & \\
\hline Gonyualax polygramma Stein ${ }^{3(\mathrm{R})}$ & & 0.146 & & & & & & & & & \\
\hline $\begin{array}{l}\text { Gonyaulax spinifera (Claparede et } \\
\text { Lachmann) Diesing, } 1866^{2(\mathrm{R})}\end{array}$ & & & & & & & & & 0.390 & & \\
\hline Gymnodinium sp. ${ }^{(\mathrm{R})}$ & & & & & & 4.595 & & & & & \\
\hline $\begin{array}{l}\text { Neoceratium balechii (Meave del Castillo et } \\
\text { al., 2012) Gómez et al., 2010 }\end{array}$ & & & & & & 89.522 & & & & & \\
\hline $\begin{array}{l}\text { Neoceratium breve (Ostenfeld \& Schmidt) } \\
\text { Gómez et al., 2010 }\end{array}$ & 0.129 & & & & & & & & & & \\
\hline $\begin{array}{l}\text { Neoceratium candelabrum (Ehrenberg) } \\
\text { Gómez et al., } 2001^{3(\mathrm{~F})}\end{array}$ & 0.129 & & 0.96 & & & & 1.388 & 0.404 & 6.054 & & 1.554 \\
\hline $\begin{array}{l}\text { Neoceratium carriense (Gourret) } \\
\text { Gómez et al., 2001 }\end{array}$ & & & & & & & & & & & 6.217 \\
\hline $\begin{array}{l}\text { Neoceratium concilians (Jörgensen) } \\
\text { Gómez et al., 2010 }\end{array}$ & 0.129 & & & & & & & & & & \\
\hline $\begin{array}{l}\text { Neoceratium contortum (Gourret) } \\
\quad \text { Gómez et al., } 2009^{3(\mathrm{R})}\end{array}$ & & 0.146 & & & & & & & & & \\
\hline $\begin{array}{l}\text { Neoceratium deflexum (Kofoid) } \\
\text { Gómez et al., 2001 }\end{array}$ & 1.686 & 4.692 & 7.84 & 1.465 & & & 13.425 & 1.417 & 22.070 & 1.397 & 14.766 \\
\hline $\begin{array}{l}\text { Neoceratium dens (Ostenfeld \& Schmidt) } \\
\text { Gómez et al., 2009 }\end{array}$ & & & & & & & 2.314 & 1.619 & 4.492 & 1.552 & \\
\hline $\begin{array}{l}\text { Neoceratium extensum (Gourret) } \\
\quad \text { Gómez et al., } 2010^{2(\mathrm{R})}\end{array}$ & 0.518 & & & & & & & & & & \\
\hline $\begin{array}{l}\text { Neoceratium falcatum (Kofoid) } \\
\text { Gomez et al., } 2010^{3(\mathrm{R})}\end{array}$ & & 0.293 & & & & & & & & & \\
\hline $\begin{array}{l}\text { Neoceratium furca (Ehrenberg) } \\
\text { Gómez et al., 2001(D) }\end{array}$ & 0.129 & 1.466 & 0.8 & 0.325 & 1.587 & 0.919 & 12.962 & 8.906 & 1.562 & 13.198 & 3.108 \\
\hline $\begin{array}{l}\text { Neoceratium fusus (Ehrenberg) } \\
\text { Gómez et al., } 2009^{2(\mathrm{~F})}\end{array}$ & & 0.586 & & 0.325 & 0.396 & 1.102 & 3.703 & 2.024 & 6.445 & 0.776 & \\
\hline $\begin{array}{l}\text { Neoceratium gravidum (Gourret) } \\
\text { Gómez et al., } 2010^{3(\mathrm{R})}\end{array}$ & & & 0.16 & 0.162 & & & & & & & \\
\hline $\begin{array}{l}\text { Neoceratium horridum var buceros } \\
\text { (Gran) Gómez et al., } 2009^{3(\mathrm{D})}\end{array}$ & 1.815 & 0.879 & 9.92 & 0.651 & & & 1.851 & 1.821 & 0.390 & 0.155 & 2.590 \\
\hline $\begin{array}{c}\text { Neoceratium inflatum } \\
\text { (Kofoid) Gómez et al., } 2009^{3(\mathrm{R})}\end{array}$ & 0.129 & & & & 0.198 & & & 0.202 & & 0.155 & \\
\hline $\begin{array}{l}\text { Neoceratium longirostrum } \\
\text { (Gourret) Gómez et al., 2009(R) }\end{array}$ & & & & & & & & 1.417 & & 0.155 & 0.259 \\
\hline
\end{tabular}




\section{Continued}

\begin{tabular}{|c|c|c|c|c|c|c|c|c|c|c|c|}
\hline $\begin{array}{l}\text { Neoceratium lunula (Schimper ex } \\
\text { Karsten) Gómez et al., } 2001^{3(\mathrm{~F})}\end{array}$ & 0.129 & & 0.8 & 0.162 & & & & & 0.390 & & \\
\hline $\begin{array}{l}\text { Neoceratium macroceros } \\
\text { (Ehrenberg) Gómez et al., } 2001^{3(\mathrm{R})}\end{array}$ & & & & 0.814 & & & 0.925 & & & & \\
\hline $\begin{array}{c}\text { Neoceratium ranipes (Cleve) } \\
\text { Gómez, 2010 }\end{array}$ & & & 0.16 & 0.325 & & & & & & & \\
\hline $\begin{array}{l}\text { Neoceratium symetricum } \\
\text { (Cleve) Gómez et al., 2001 }\end{array}$ & 0.129 & & & 0.162 & & & & & & & \\
\hline $\begin{array}{c}\text { Neoceratium trichoceros } \\
\text { (Ehrenberg) Gómez et al., 2009 }\end{array}$ & 1.037 & 0.146 & 2.08 & 3.908 & 0.793 & & 8.796 & 1.012 & 20.117 & 0.155 & 10.103 \\
\hline $\begin{array}{l}\text { Neoceratium tripos } \\
\text { (Müller) Gómez et al., 2001 }\end{array}$ & 1.945 & 0.146 & 9.28 & 3.257 & & 0.551 & 27.314 & 3.846 & 23.242 & 6.055 & 14.248 \\
\hline Neoceratium sp. ${ }^{(0)}$ & & & 27.2 & 2.442 & & & & & & & \\
\hline Ornithocercus steinii Schütt, $1900^{3(\mathrm{R})}$ & 0.129 & & & & 0.198 & & & & & & \\
\hline Prorocentrum compressum (Bailey) $)^{3(\mathrm{R})}$ & & 0.146 & & & & & & & & & \\
\hline Prorocentrum gracile Schutt, $1895^{3(\mathrm{D})}$ & 0.129 & 5.718 & 0.32 & 0.325 & 0.793 & & 6.018 & 0.202 & 0.585 & 6.521 & \\
\hline Prorocentrum sp. ${ }^{(\mathrm{R})}$ & & 0.439 & & & 2.182 & & & & & & \\
\hline $\begin{array}{l}\text { Protoperidinium conicum } \\
\text { (Gran) Balech, } 1974^{3(\mathrm{R})}\end{array}$ & 0.129 & & & 0.325 & 1.785 & & & & & & \\
\hline $\begin{array}{l}\text { Protoperidinium divergens } \\
\text { (Ehrenberg) Balech, } 1974^{3(\mathrm{R})}\end{array}$ & 2.594 & & & & 0.198 & & & & & & 2.849 \\
\hline $\begin{array}{l}\text { Protoperidinium latispinum } \\
\text { (Mangin) Balech, } 1974^{3(\mathrm{R})}\end{array}$ & & & & & 0.198 & & & & & & \\
\hline Protoperidinium sp. ${ }^{(\mathrm{D})}$ & 0.648 & 0.146 & 0.16 & 1.791 & 1.785 & & & & 0.976 & 6.987 & 6.476 \\
\hline $\begin{array}{l}\text { Pyrocystis fusiformis Wyville-Thompson } \\
\text { ex Blackmann, } 1902^{4(\mathrm{~F})}\end{array}$ & 1.556 & 4.252 & 2.88 & 0.977 & & & & & & & \\
\hline $\begin{array}{l}\text { Pyrocystis lunula (J. Schütt) } \\
\text { J. Schütt, } 1896^{4(\mathrm{R})}\end{array}$ & & 0.146 & & & & & & & & & \\
\hline Subtotal & 13.488 & 23.753 & 62.56 & 17.589 & 11.111 & 100 & 81.944 & 24.291 & 88.867 & 40.993 & 62.172 \\
\hline \multicolumn{12}{|l|}{ Bacillariophyta } \\
\hline $\begin{array}{l}\text { Amphora angusta var. } \\
\text { Ventricosa (Gregory) Cleve, } 1895^{2(\mathrm{R})}\end{array}$ & & & & & & & & & & & 0.259 \\
\hline $\begin{array}{l}\text { Asteromphalusheptactis } \\
\text { (Brébisson) Ralfs } 1861^{2(\mathrm{R})}\end{array}$ & & & & & & & & & & & 0.518 \\
\hline Bacteriastrum hyalinum Lauder, $1864^{3(\mathrm{R})}$ & & & & & 1.388 & & & & & & \\
\hline Chaetoceros affinis Lauder, $1864^{3(\mathrm{D})}$ & 33.981 & 11.290 & 7.04 & 2.117 & 10.119 & & & & & & 0.259 \\
\hline Chaetoceros curvisetus Cleve, $1889^{3(\mathrm{~F})}$ & & 0.293 & & 1.140 & 1.984 & & 1.388 & & & & \\
\hline Chaetoceros decipiens Cleve, $1873^{3(\mathrm{R})}$ & & & & 3.257 & 0.793 & & & & & & \\
\hline Chaetoceros didymus Ehrenberg, $1845^{3(\mathrm{D})}$ & 15.434 & 15.982 & 11.84 & 6.514 & 5.952 & & & 0.404 & & 0.310 & 1.554 \\
\hline Chaetoceros lorenzianus Grunow, $1863^{2(\mathrm{R})}$ & & & & & 0.198 & & & & & & \\
\hline Chaetoceros socialis Lauder, $1864^{2(0)}$ & & & 5.28 & & 18.452 & & & & & & \\
\hline Chaetoceros sp. $^{(\mathrm{D})}$ & 26.070 & 7.771 & 9.76 & 6.026 & 36.904 & & 1.851 & 33.400 & 6.835 & 22.360 & 19.430 \\
\hline Chaetoceros teres Cleve, $1896^{3(\mathrm{~F})}$ & 4.539 & 0.439 & 0.48 & 0.651 & 1.587 & & & & & & \\
\hline Coscinodiscus granii Gough, $1905^{3(\mathrm{R})}$ & & & & & & & & & 0.585 & & \\
\hline
\end{tabular}




\section{Continued}

Coscinodicus heteroporus Ehrenberg, $1844^{3(\mathrm{D})}$

Coscinodiscus radiatus Ehrenberg $1840^{3(\mathrm{R})}$

$$
\text { Coscinodiscus sp. } .^{(\mathrm{D})}
$$

Ditylum brightwelli

(West) Grunow, $1883^{3(\mathrm{~F})}$

Eucampia zoodiacus Ehrenberg $1839^{3(\mathrm{R})}$

Guinardia delicatula

(Cleve) Hasle, $1997^{2(\mathrm{R})}$

\section{Guinardia flaccida}

(Castracane) Peragallo, 1892 ${ }^{3(\mathrm{R})}$

Guinardia striata (Stolterfoth) Hasle, $1996^{3(\mathrm{R})}$

Hemiaulus sinensis Greville, $1865^{2(\mathrm{R})}$

Leptocylindrus danicus Cleve, $1889^{3(\mathrm{R})}$

Leptocylindrus minimus Gran, $1915^{3(\mathrm{R})}$

Licmophora abbreviata Agardh, 1831 2(R)

Nitzschia pacifica Cupp, 1943 ${ }^{3(\mathrm{R})}$

$$
\text { Nitzschia sp. }{ }^{(\mathrm{F})}
$$

Planktoniella sol (Wallich) Schütt, $1893^{4(\mathrm{~F})}$

Proboscia alata (Brightwell) Sundström, $1986^{3(\mathrm{D})}$

Rabdonema sp. ${ }^{(\mathrm{D})}$

Rhizosolenia hebetata Bailey, 1856

Rhizosolenia imbricata Brightwell, 1858 $3(\mathrm{R})$

Rhizosolenia setigera Brightwell, 1858 2(R)

Skeletonema costatum

Stephanopyxis palmeriana (Greville) Grunow, 1884 ${ }^{3(\mathrm{R})}$

Thalassiothrix longissima Cleve \& Grunow, $1880^{3(\mathrm{R})}$

\section{Subtotal}

\section{Heterokontophyta}

Dictyocha fibula Ehrenberg, 18394(R)

Dictyocha octonaria Ehrenberg $1844^{4(\mathrm{R})}$

Subtotal

\section{Cyanobacteria}

Phormidium limosum (Dillwyn) P.C. Silva, $1996^{1(\mathrm{~F})}$

Microcystis aeruginosa

(Kützing) Kützing, 1846 ${ }^{1(\mathrm{R})}$

Spirulina sp. ${ }^{(\mathrm{R})}$ $\begin{array}{lllll}0.648 & 3.812 & 0.16 & 14.169 & 0.198\end{array}$

98

$1.612 \quad 0.32 \quad 14.332$

0.129

0.43

0.16

2.117

0.198

0.198

5.263

4.347

$0.879 \quad 2.768$

$1.466 \quad 0.16 \quad 1.140$

0.198

0.162

1.397

0.310

0.155

0.162

0.488

0.651

0.925

$4.048 \quad 1.171$

3.416

1.214

$0.310 \quad 0.259$

$12.023 \quad 0.16$

6.188

0.595

$4.409 \quad 16.715$

$\begin{array}{lllll}1.037 & 3.225 & 1.92 & 16.938 & 1.190\end{array}$

$31.376 \quad 1.562$

0.621

4.629

2.314

$0.162 \quad 1.388$

0.310

0.129

$2.931 \quad 6.746$

0.325

$86.51175 .953 \quad 37.28$

0.0

$16.666 \quad 75.708 \quad 11.132$
0.146

0.146

0.293
0.198

0.198

0.595

0.925

1.086

0.162

0.462

$\begin{array}{lll}0.16 & 0.162 & 0.595\end{array}$

1.388

1.086 
Table 4. Characteristics of phytoplankton communities from Acapulco Bay, Mexico. Dino. = Dinoflagellates, Diat. = Diatoms, BPI = Berger-Parker Index; $\mathrm{H}=$ Shannon-Wiener diversity index, $\mathrm{J}=$ Equity index.

\begin{tabular}{ccccccccc}
\hline MONTH & $\begin{array}{c}\text { No. } \\
\text { of species }\end{array}$ & $\begin{array}{c}\text { Dino. } \\
\text { Rel. Abun. }\end{array}$ & $\begin{array}{c}\text { Diat. } \\
\text { Rel. Abun. }\end{array}$ & $\begin{array}{c}\text { Others } \\
\text { Rel. Abun. }\end{array}$ & Dominant species & BPI & $\mathrm{H}^{\prime}$ & $\mathrm{J}^{\prime}$ \\
\hline January-11 & 30 & 13.48 & 86.51 & 0.0 & Chaetoceros affinis & 33.98 & 1.98 & 0.58 \\
February & 34 & 23.75 & 75.95 & 0.29 & Chaetoceros didymus & 15.98 & 2.62 & 0.74 \\
March & 25 & 62.56 & 37.28 & 0.16 & Neoceratium sp. & 27.2 & 2.35 & 0.73 \\
April & 38 & 17.58 & 82.24 & 0.16 & Rhizosolenia hebetata & 16.93 & 2.8 & 0.77 \\
September & 31 & 11.11 & 88.09 & 0.79 & Chaetoceros sp. & 36.9 & 2.23 & 0.65 \\
April-12 & 07 & 100.0 & 0.0 & 0.0 & Neoceratium balechii & 89.52 & 0.48 & 0.25 \\
May & 20 & 81.94 & 16.66 & 1.85 & Neoceratium tripos & 27.31 & 2.41 & 0.8 \\
June & 18 & 24.29 & 75.7 & 0.0 & Chaetoceros sp. & 33.4 & 1.92 & 0.66 \\
July & 21 & 88.86 & 11.13 & 0.0 & Neoceratium tripos & 23.24 & 2.17 & 0.71 \\
October & 25 & 40.99 & 57.91 & 1.08 & Chaetoceros sp. & 22.36 & 2.3 & 0.71 \\
November & 19 & 62.17 & 37.82 & 0.0 & Chaetoceros sp. & 19.43 & 2.38 & 0.8 \\
\hline
\end{tabular}

The highest diversity values were reached in February and April 2011 (2.62 and 2.8 respectively) and the lowest in April 2012 (0.48 bits). The comparison of similarity in species composition between sampled months indicated that the similarity percentages were generally low, it was only during June and October 2011 that a percentage higher than $70 \%$ was recorded. This indicates that the structure of the phytoplankton community fluctuates widely in regards of time. Three groups were clearly observed, the first comprised the dry months of the sampling period (February, March, and April 2011) and September of that same year; the second group only includes April 2012 were an HAB of Neoceratium balechii was recorded; and the third group was found in the rest of the months of 2012 (Figure 1).

\section{Discussion}

\subsection{Species Composition}

The dinoflagellate group (42 species) dominated in terms of species richness in the phytoplankton community of Acapulco Bay; however, its total relative abundance was significantly lower than the found for diatoms. This result coincides with [3] [4] [9] [10]. In regards to species richness in the same study area, however it disagrees with the pattern observed in other studies of phytoplankton composition from other tropical locations, in which diatoms dominate in terms of number of species [11]-[15]. The groups of phytoplankton species are considered to be accurate indicators of water masses [16]. Dinoflagellates are best adapted to oceanic environments, while diatoms to coastal ones [11] [17]. Hence, our results suggest that the environmental conditions within the bay change throughout the year given the variation of environmental parameters, as it is shown in the results of PCA.

Moreover, the environmental changes that occur in the water mass found in the bay are reflected in the characteristics of the phytoplankton community, since more than $70 \%$ of the dinoflagellates and diatoms that inhabit therein are adapted to live in both neritic and oceanic environments, i.e., adiaphoric species [11]. There was no estuarine or freshwater influence observed in the phytoplankton species composition.

Different species dominated numerically on each of the months, indicating a great variability in species composition through time. The diatom Chaetoceros sp. dominated during the raining season (September 2011), recording a great relative abundance $36.9 \%$ (Table 4); while its relative abundance decreased significantly in the dry season months ( $<10 \%$ from February to April 2011). The dinoflagellate Neoceratium balechii dominated during April 2012 with 89.52\% of relative abundance, however it was only observed in this month causing a $\mathrm{HAB}$, hence it was classified as an occasional dinoflagellate (Table 4).

The great abundance that Neoceratium tripos presented during some of the months may be attributed to the 


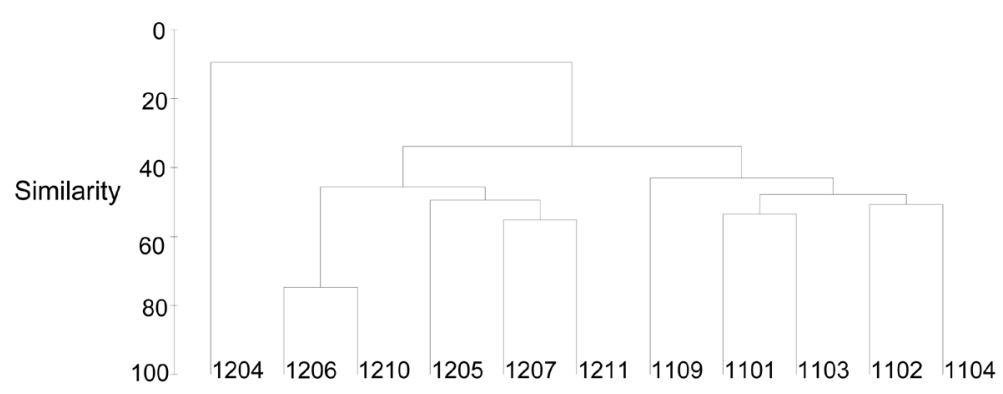

Figure 1. Similarity percentages among phytoplankton samplings in Acapulco Bay, Mexico.

fact that dinoflagellates from genus Neoceratium (previous Ceratium) can form chains of up to four cells; at some regions of the Pacific and the Caribbean this type of chains allows them to remain floating in the photic zone [17]. In this regard, the genus Neoceratium was the most abundant and included a total of 23 dinoflagellate species, which together represented $31.9 \%$ of the total of cells within the phytoplankton community.

\subsection{Community Structure}

Some studies indicate that changes in the phytoplankton community structure might be related to small changes in water temperature [12] [13] or to the different strategies of the phytoplanktonic groups for nutrient absorption in the water column [18]. Hence, the greatest abundances of some of the phytoplanktonic species found during May, September, and October 2012 can be attributed to water temperatures which are significantly warmer [3] [9] sincehigh temperatures can enhance growth of some dinoflagellate populations. In addition, diatoms respond rapidly to the increase of nutrient concentration [19], thus their growth can be faster than the found for dinoflagellates, as it occurs during the raining season.

At least six of the 42 identified dinoflagellate species (Dinophysis caudata, Gonyaulax polygramma, G. spinifera, Neoceratium furca, $N$. fusus, and $N$. tripos), have been related to HABs or red tides in other Mexican localities [20]. Nevertheless, only the species Neoceratium furca and $N$. tripos were abundant and frequent (dominant) during the sampling months. Neoceratium tripos reached a maximun relative abundance of $27.3 \%$ in May 2012, a month after the HAB caused by Neoceratium balechii (Table 4).

The pattern of species distribution found in the phytoplankton community from Acapulco Bay was similar to the observed in other marine or estuarine communities, given it was structured by a low number of dominant species (seven dinoflagellates and seven diatoms), which contributed with more than $78 \%$ of the total abundance, as well as by a high number of occasional and rare species $(>64 \%)$.

The total richness ( 82 species) recorded herein, is found within the range of the species reported for the study area [3] [9] [13], as well as for other countries with similar environmental conditions [11] [12] [14]. However, [10] reported 641 taxa for Acapulco Bay and adjacent areas, which belonged to eight divisions of algae, where the most diverse group was Dinophyta with 347 taxa, followed by Bacillariophyta with 274 taxa. These findings were made through a decade of studies, including an intensive research with bimonthly samplings using a phytoplankton net, bottle, and observations on living samples that went from February 2010 to February 2011; in the present study, species were collected exclusively using a $150 \mu \mathrm{m}$ plankton net. The diversity values $(0.48$ a 2.8 bits) are also similar to the previously found in the study area, where [3] [9] report diversity values (Shannon-Wiener index) that ranged from 1.45 to 4.06 bits, as well as to findings made in other localities of the Tropical Pacific. [11] [20] found diversity values (Shannon-Wiener index) ranging from 3.5 to 5.3 bits, while [21] recorded values from 2.5 to 4 bits. According to [22], the analysis of several phytoplanktonic communities from different oceanographic localities in the Caribbean, African northeastern Atlantic, and the Mediterranean has provided a wide series of Shannon's diversity values which range from 2.4 to 2.6 bits. In regards to the aforementioned, the phytoplankton diversities in Acapulco Bay are equal to the mode of the most frequent diversities found in the open ocean. During April 2012, the minimum value (0.48 bits) was observed, which coincides with the occurrence of a HAB dominated by Neoceratium balechii.

The greatest diversity values recorded in February (2.62) and April (2.8) 2011 may have been found because communities were dominated only by a few species, in contrast to the rest of the months, hence, species abundances were more homogeneous (equity $\geq 0.70$, Table 4 ). In addition, the low similarity values observed 
(Figure 1), indicate that the species composition differed in most of the months given the environmental variability recorded through time. It is shown in the results of PCA too.

Results indicate that species abundance and composition within the phytoplankton community presented significant temporal fluctuations because of variations in the environmental conditions. In this regard, the environmental variation caused by the dry and raining seasons results in significant changes in nutrient concentration, favoring population growth of some dinoflagellate or diatom species throughout the year. The phytoplankton community proved to be an accurate indicator of environmental changes in Acapulco Bay.

\section{References}

[1] Silver, W. and Platt, T. (1978) Energy Flux in the Pelagic Ecosystem: A Time-Dependent Equation. Limnology Oceanography, 23, 813-816. http://dx.doi.org/10.4319/lo.1978.23.4.0813

[2] Steel, J.H. (1976) Patchiness. In: Cushing, D.H. and Walsh, J.J., Eds., The Ecology of the Seas, Blackwell Scientific Publications, London, 98-115.

[3] Rojas-Herrera, A.A., Violante-González, J., García-Ibáñez, S., Sevilla-Torres, V.M.G., Gil-Guerrero, J.S. and FloresRodríguez, P. (2012) Temporal Variation in the Phytoplankton Community of Acapulco Bay, Mexico. Microbiology Research, 3, 13-19.

[4] Moreno-Díaz, G., Rojas-Herrera, A.A., González-González, J., Violante-González, J., Rosas Acevedo, J.L. and García Ibáñez, S. (2015) Temporal and Spatial Variation in the Phytoplankton Community of Acapulco Bay, Mexico. Revista Bio Ciencias, 3, 88-102.

[5] Sokal, R.R. and Rohlf, F.J. (1998) Biometry. 2nd ed. W. H. Freeman and Company, San Francisco, 859 pp.

[6] Magurran, A. (1991) Ecological Diversity and Its Measurement. Princeton University Press, Princeton, 178 pp.

[7] Krebs, C.J. (1999) Ecological Methodology. Addison-Welsey Educational Publishers, Inc., Boston, 654 pp.

[8] Digby, P. and Kempton, R. (1987) Multivariate Analysis of Ecological Communities. Chapman and Hall, London, 204 pp.

[9] Rojas-Herrera, A.A., Violante-González, J., Sevilla-Torres, V.M.G., Gil-Guerrero, J.S., Flores-Rodríguez, P. and Rendón-Dircio, J.A. (2012) Species Composition and Abundance of Phytoplankton Communities in Acapulco Bay, Mexico. International Research Journal of Microbiology, 3, 307-316.

[10] Meave-del Castillo, M.H., Zamudio-Resendiz, M.E. and Castillo-Rivera, M. (2012) Riqueza fitoplanctónica de la Bahía de Acapulco y zona costera aledaña, Guerrero, México. Acta Botánica Mexicana, 100, 405-487.

[11] Peña, V. and Pinilla, G.A. (2002) Composición, distribución y abundancia de la comunidad fitoplanctónica de la ensenada de Utría, Pacífico colombiano. Revista de Biología Marina y Oceanografía, 37, 67-81.

[12] Ochoa, N. and Tarazona, J. (2003) Variabilidad temporal de pequeña escala en el fitoplancton de Bahía Independencia, Pisco, Perú. Revista Peruana de Biología, 10, 59-66.

[13] Varona-Cordero, F. and Gutiérrez-Mendieta, F.J. (2006) Composición estacional del fitoplancton de dos lagunas del Pacífico tropical. Hidrobiológica, 16, 159-174.

[14] Moreira, A., L Seisdedo, M., Leal, S., Comas, A., Delgado, G., Regadera, R., Alonso, C., Muñoz, A. and Abatte, M. (2007) Composición y abundancia del fitoplancton de la Bahía de Cienfuegos, Cuba. Revista de Investigaciones Marinas, 28, 97-109.

[15] Vargas-Montero, M., Bustamante, E.F., Guzmán, J.C., Vargas, J.C., et al. (2008) Florecimientos de dinoflagelados nocivos en la costa Pacífica de Costa Rica. Hidrobiológica, 18, 15-23.

[16] Castillo, F. and Vidal, A. (1982) Fitoplancton del Pacífico colombiano como indicadores de masas de agua. Fase CIOH, Cartagena, 1-57.

[17] Castillo, F. (1984) Fitoplancton del Pacífico colombiano como indicador de masas de agua. Erfen IV. Biología Pesquera, 13, 67-70.

[18] Langlois, G.W and Smith, P. (2001) Phytoplankton In: Biology and Ecological Niches in the Gulf of the Farallones. U.S. Geological Survey, Reston, 32-35.

[19] Örnólfsdóttir, E.B., Lumsden, E. and Pinckney, J.L. (2004) Phytoplankton Community Growth-Rate Response to Nutrient Pulses in a Shallow Turbid Estuary, Galveston Bay, Texas. Journal of Plankton Research, 26, 325-339.

[20] Cortés-Altamirano, R. (1998) Informe regional sobre mareas rojas en México. IOCARIBE-ANCA. II Taller regional, Ciudad de la Habana, 4.

[21] Sánchez, E. (1996) Caracterización espacial del fitoplancton nerítico en el Pacífico Colombiano durante julio-agosto de 1994. Tesis (Biólogo), Facultad de Ciencias, Universidad del Valle, Cali, 60.

[22] Margalef, R. (1980) La Biosfera. Entre la termodinámica y el juego. Omega, Barcelona, 236. 